\title{
Organic geochemistry and mineralogical characterization of the Paleocene Ranikot Formation shales in selected areas of Southern Indus Basin Pakistan
}

\author{
Hussain Asghar ${ }^{1, *}$, Saeed Abbas², Muhammad Sabir Khan ${ }^{1}$, Samina Jahandad ${ }^{3}$, \\ Muhammad Hanif ${ }^{4}$, Muhammad Saleem Mughal ${ }^{1}$, Gulfam Hussain ${ }^{5}$ \\ ${ }^{1}$ Institute of Geology University of Azad Jammu \& Kashmir Muzaffarabad, \\ Azad Kashmir Pakistan \\ ${ }^{2}$ Oil \& Gas Development Company Limited (OGDCL), Pakistan \\ ${ }^{3}$ Hydrocarbon Development Institute of Pakistan (HDIP) \\ ${ }^{4}$ National Centre of Excellence in Geology (NCEG), University of Peshawar, Pakistan \\ ${ }^{5}$ University of Chinses Academy of Sciences, Beijing, 100101, China \\ *Corresponding author: geologistturi12@gmail.com
}

\begin{abstract}
Southern Indus Basin is one of the promising regions in Pakistan as a commercially producing oil and gas perspective. The current research presents the geochemical characterization of the Ranikot Formation shales from Southern Indus Basin based on total organic carbon (TOC), Rock-Eval (RE) pyrolysis, organic petrography, gas chromatography-mass spectrometry (GC-MS), and x-ray diffraction (XRD) analyses. The average TOC of Ranikot shale is $4.6 \mathrm{wt}$. \%, indicating very good hydrocarbon potential. Types III/IV kerogens were identified in the Ranikot shale. The maceral data also suggest that the Type of kerogen present in the Ranikot shale is dominantly Types II-III, with the minor occurrence of Type IV. The vitrinite reflectance, pyrolysis $T_{\max }$ and methylphenanthrene indices values specify immature levels of the shales. The normal alkane data reflect that marine macrophyte, algae, and land plants were contributed to the organic matter of Ranikot shales. Dibenzothiophene/phenanthrene ratio (0.11), phytane/n- $\mathrm{C}_{18}$ ratio (0.53), pyrite, and glauconite elucidate that the depositional environment of the Ranikot shale is marine.

The XRD analysis of the shale from the Ranikot Formation revealed that it is brittle shale and dominated by 39.5 to 50.9 wt. \% quartz. The present study, integration with the US EIA report demarcated the Ranikot Formation influential horizon as a shale gas resource.
\end{abstract}

Keywords: Organic geochemistry ;Ranikot shales; shale gas; southern Indus Basin; source rock.

\section{Introduction}

Organic geochemical investigation of a petroleum source rock in a particular Basin indicates crucial information. Geochemical signatures are used to evaluate the type, age, depositional environments, and maturity of the potential source rock in a sedimentary Basin. The hydrocarbon potential of any source rock is strongly dependent on organic matter richness, volume, and maturity 
(Tissot \& Welte, 1984; Peters \& Cassa, 1994; Bahman et al., 2022 ). Southern Indus Basin is one of the prolific petroleum-producing regions in Pakistan, and the Basin is still being explored via modern hydrocarbon exploration techniques for the finding of sustainable hydrocarbon reserves. The Cretaceous age Goru Formation sandstone is the leading reservoir of all the commercial oil and gas innovations in the Southern Indus Basin. The Sembar Formation shales (Cretaceous age) are considered as an important source rock for all profitable oil and gas developments in the Southern Indus Basin. The Sembar and Talhar shales (Cretaceous age) are studied by various researchers for the hydrocarbon source rock potential, though to date no commercial and productive shale oil or gas wells have been drilled into Sembar shales (Quadri et al., 1968; EIA, 2015; Sheikh \& Giao, 2017; Ehsan et al., 2018; Ahmad et al., 2019; Awan et al., 2021). The Ranikot Formation is also studied by Shah \& Ahmed (2018) in Punjab Platform Middle Indus Basin Pakistan. According to their investigations, Ranikot Formation has poor potential as a source rock for oil but has a minor potential for gas aspect in Punjab Platform Middle Indus Basin.

The Paleocene Ranikot Formation shales in the Southern Indus Basin, which are specific attention of the current research have been cursorily investigated by the United States Energy Information Administration (EIA, 2015) for shale oil and gas. The technically recoverable shale gas resources of the Ranikot Formation are 4-Trillion cubic feet. Nevertheless, the shale of the Ranikot Formation is not being evaluated in detail from an organic geochemical perspective. Thereby no comprehensive research data is available about Ranikot Formation shales from Southern Indus Basin (EIA, 2015).

Thus more consideration should be paid to the Ranikot Formation shales in the Southern Indus Basin. In this research, the hydrocarbon source rock potential was assessed using organic geochemical techniques. The origin and type of organic matter were determined and their thermal maturity was evaluated. Additionally, the shale gas aspect of the Ranikot Formation is also studied. For geochemical and mineralogical examination of Ranikot Formation shales, three wells (Ranpethani, Hashim Kher \& Sono Deep) are selected from Southern Indus Basin (Figure 1).

\section{Geological setting}

Southern Indus Basin is bounded by Mari-Kandkot High on the north, Indian shield to the east, offshore Indus on the south while its western boundary is confined by Chaman and Ornachnal faults (Figure 1). Southern Indus Basin experienced extensional tectonics in the Late Paleozoic (Powell, 1979; Zaigham, 1991). Different researchers have portrayed the tectonic history of the Southern Indus Basin (Powell, 1979; Biswas, 1982; Zaigham, 1991). According to Zaigham and Mallick (2000), rifting was initiated in Gondwana land in the Late Paleozoic. The progressive rifting resulted in thinning and stretching of the continental lithosphere, followed by up warping and extensional faults. The basaltic lava poured out along the rift. The rift opened into an ocean with normal faults. At the end of Paleozoic and in the Early Mesozoic with the cessation of basaltic lava flow spreading was stopped. 
The failed rift became the site of deposition of sediments that formed the Southern Indus Basin. On cooling, the Basin subsidence occurred in Mesozoic and Tertiary (Shah, 2009). The sediments were deposited in a subsiding Basin forming a thick sequence of rocks. Stratigraphically the Southern Indus Basin covers an area of 250,000 $\mathrm{km}^{2}$ with a 13 to $16 \mathrm{~km}$ thick sequence of Mesozoic and Cenozoic rocks (Shah, 2009). The northwestern margin of the Indian Plate remained submerged under the seawater during the Late Paleozoic, Mesozoic, Paleocene, and Eocene (Shah, 2009).

On regression of Tethys ocean, most of the area was covered with the epi-continental sea during Paleocene and Eocene Epochs (Shah, 2009). The marine sediments were deposited during this time in the Lower Indus Basin. Many thousand meter thick calcareous and argillaceous sediments of the Mesozoic are exposed in the Sulaiman-Kirthar Provinces and axial belts on the western margin of the Indus Basin (Shah, 2009). The Paleocene-Early Eocene rocks were deposited in the marine environments in the Basin. The Tertiary rocks are exposed in Khairpur and Hyderabad in the Lower Indus Basin (Zaigham \& Mallick, 2000). On the eastern side of the Basin, Tertiary rocks are exposed in Jaisalmer and Rann Kutch areas (Biswas, 1982). The project area is comprised of sedimentary successions ranging from Triassic to recent (Figure 2).

The current study is restricted to shales of the Ranikot Formation and hence their lithology is briefly described. According to Shah (2009), the Ranikot Group comprises of Khadro, Bara, and Lakhra formations and is concisely discussed in this paper. However, during the current study, the Ranikot Group is considered as a Ranikot Formation of Shah (1977). The Khadro Formation comprises sandstone, shale, and limestone (Shah, 2009). The Bara Formation comprises abundant sandstone with minor shale and volcanic debris (Cheema et al., 1977). Lakhra Formation comprises limestone and exhibits a variable color at some locations (Shah, 2009).

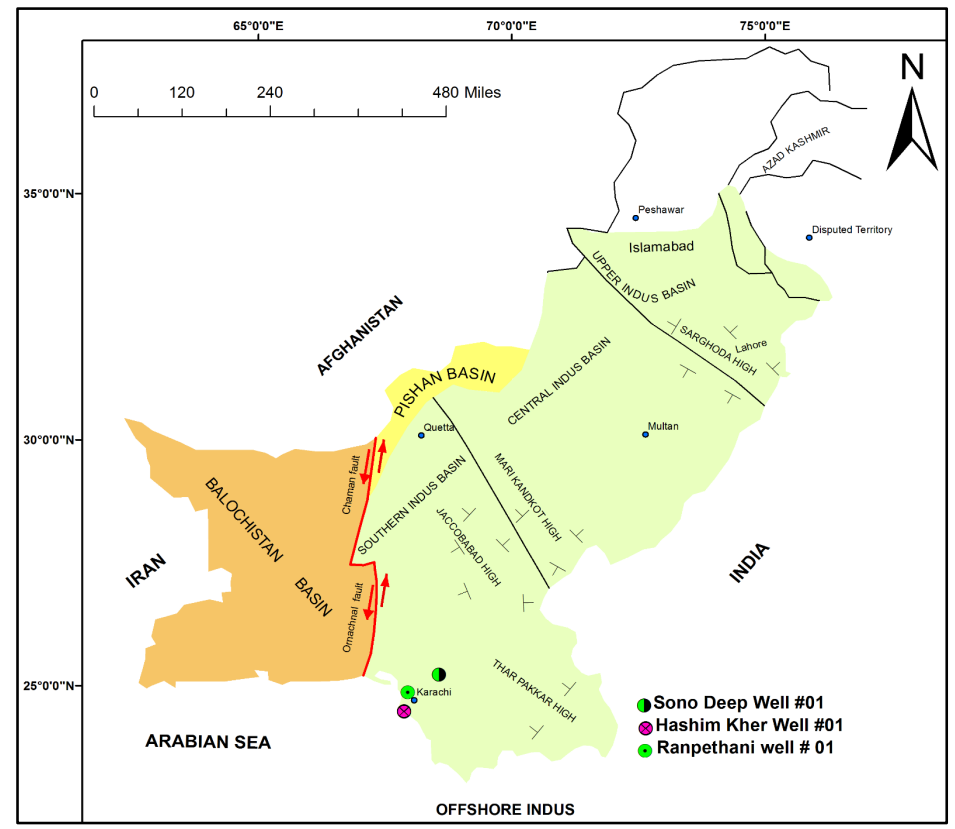

Fig. 1. Map showing sedimentary Basins of Pakistan (Farah et al., 1984). The research area is represented by three wells. 


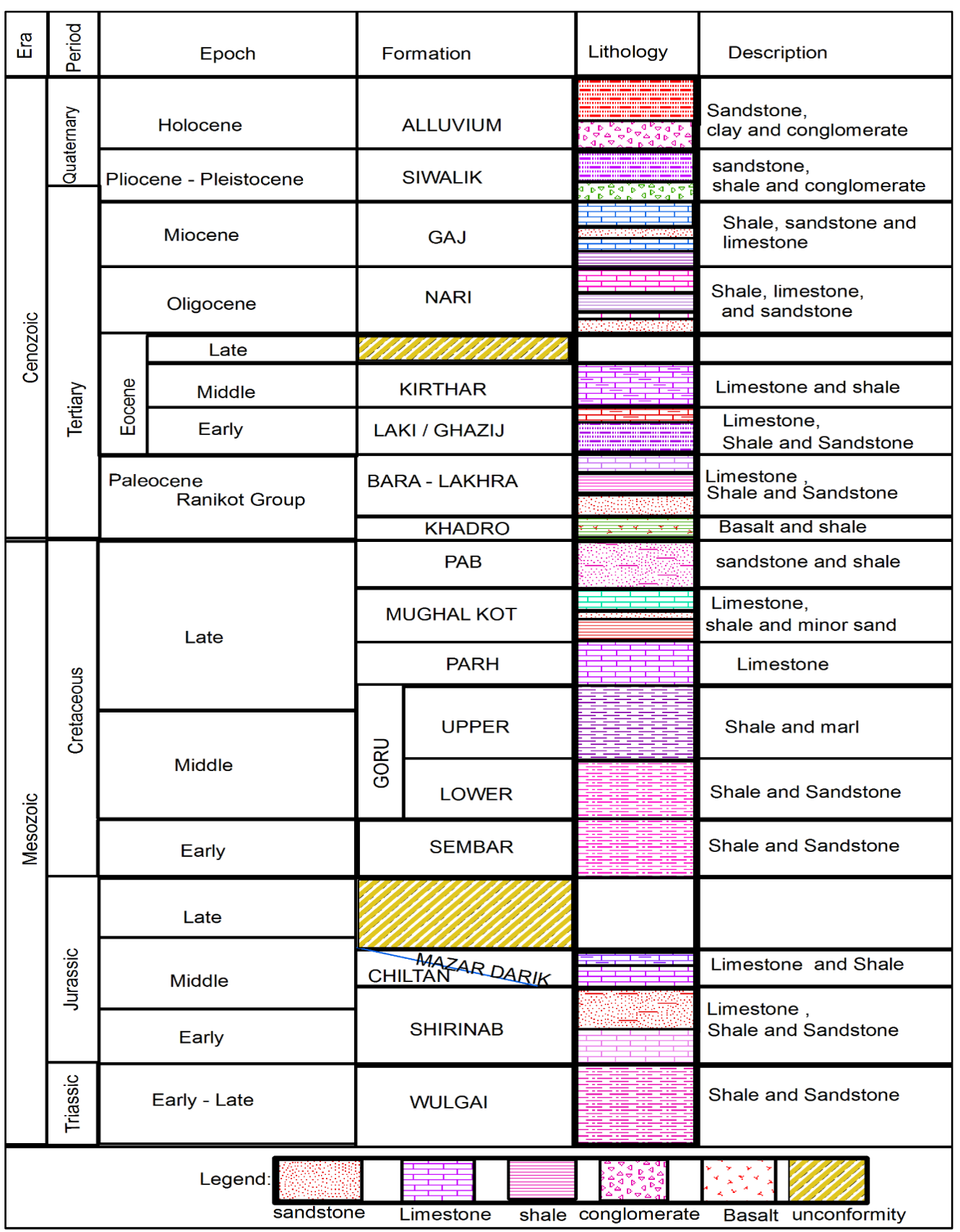

Fig. 2. Showing stratigraphy of Southern Indus Basin Pakistan (after Shah, 1977; Raza et al., 1990).

\section{Material and methods}

For an organic geochemical characterization and bulk mineralogy 21 well-cutting samples (Table 1) of the Paleocene Ranikot Formation shales were provided by Oil \& Gas Development Company Limited (OGDCL). The wells were drilled in Ranikot Formation Southern Indus Basin Sindh Province Pakistan (Figure 1). The well-cutting samples were washed with distilled water before geochemical analyses. Total organic carbon (TOC) and Rock-Eval (RE) pyrolysis analyses were 
carried out on 21 samples. TOC and RE were measured from Rock-Eval 6 instrument. The Soxhlet extraction process was used for extractable organic matter (EOM) of twenty gram pulverized shale of the Ranikot Formation in the Ranpethani well. Pulverized shale samples were treated with dichloromethane (DCM) and methanol in a ratio of 97:3 respectively at a rate of seven hours per day. The total time required to extract organic matter from one sample was 24 hours. A mixture of dichloromethane and methanol was taken in the round bottom flask, while samples were placed in thimbles and topped with glass wool. The solvent was heated at about $30^{\circ} \mathrm{C}$ and vaporized in boiling flasks. The sample was cooled $\left(16^{\circ} \mathrm{C}\right)$ by using cooled water via a machine. This cooled solvent was used to extract EOM from the shale samples. The extracted EOM was then transformed into pre-weighed vials for deasphalting. Asphalt fraction was removed from extractable organic matter by adding n-hexane. The solution was then kept in a dark place for 8 hours and filtered. The asphalts were immiscible in n-hexane and extracted from EOM. Gas chromatography-mass spectrometry (GC-MS) analyses were carried out on 2 samples for biomarker data. GC-MS analysis of the whole oil was performed with Varian Ion Trap GC-MS 4000, an instrument with Column C98911, VF-IMS, and $30 * 0.25$. The temperature of the injector was $300{ }^{\circ} \mathrm{C}$. The initial temperature was set to $50{ }^{\circ} \mathrm{C}$ for $1.5 \mathrm{~min}$, then ramped to $300{ }^{\circ} \mathrm{C}$ at $3.5^{\circ} \mathrm{C} / \mathrm{min}$. Helium was used as a carrier and was set to flow at a rate of $1.0 \mathrm{ml} / \mathrm{min}$.

Organic petrography analyses were performed on two samples. The samples Ranikot Formation shales of 0.8 to $2 \mathrm{~mm}$ particle size were embedded in Araldite and polish sections were prepared. Ranikot shale samples were studied under white and blue light using spectrometer system MCS CCD ZIM Zeiss microscope. For the standard of zero, 0.589\%, YAG $0.907 \%$, and GGG $1.711 \%$ reflectance were utilized for calibration. X-ray diffraction (XRD) analyses were performed on two samples. Ranikot Formation shales were ground to powder form by hand before being analyzed in an X-ray diffractometer (model X Pert PRO). XRD analysis was carried out using one gram of powder sample. The x-ray instrument was operated at the condition of an x-ray with wavelength $\mathrm{Cu} \mathrm{K}$ alpha radiations $1.540598 \mathrm{~nm}$, generating voltage 40-kilo volts, tube current 30 milliamperes, divergent slit fix, receiving slit 0.1 , scan step size continuous, scan step size 0.01 , and time per scan is 0.25 .

\section{Results and discussion}

\subsection{Hydrocarbon generation potential and Type of kerogen}

TOC is one of the foremost elements in controlling source rock quality and organic richness (Peters, 1986; Jarvie, 1991; Peters \& Cassa, 1994). The results of the TOC contents and pyrolysis parameters of the Ranikot Formation shales are illustrated in Table 1. The current TOC values are correlated with Jarvie (1991) to evaluate the hydrocarbon potential of the Ranikot Formation shales. The TOC values of the Ranikot shales are ranging from 0.65 to $37.62 \mathrm{wt}$. \%. The values indicate that the Ranikot shales have fair to excellent hydrocarbon potential. The average TOC of the Ranikot shales is 4.6 wt. \%. This value designates that the shales have very good hydrocarbon 
potential. The $\mathrm{S}_{1}$ values of the Ranikot Formation shales vary from 0.00 to $2.82 \mathrm{mg} \mathrm{HC} / \mathrm{g}$ rock. The values reflect that studied samples have poor to very good hydrocarbons generation potential.

The $\mathrm{S}_{2}$ values of the shales are in the range of 0.02 to $87.97 \mathrm{mg} \mathrm{HC} / \mathrm{g}$ rock. The values are indicative of poor to excellent hydrocarbon generative potential. $S_{1}$ and $S_{2}$ values of the Ranikot shales are correlated with Peters (1986). The hydrocarbon potential is further evaluated from the cross-plot relation between TOC versus depth (Figure 3). The diagram indicates most of the samples are in the range between good to very good hydrocarbon potential. The hydrocarbon generation potential of the Ranikot shale is also represented by pyrolysis parameter generation potential (GP). The poor and very good hydrocarbon generation potential of the source rock can be expressed by GP values. GP value less than $2 \mathrm{mg} \mathrm{HC} / \mathrm{g}$ rock indicates poor, and GP value higher $10 \mathrm{mg} \mathrm{HC} / \mathrm{g}$ rock shows very good hydrocarbons generation potential of the source rock (Ghori and Haines, 2007; Tissot and Welte, 1984). GP (Table 1) of the Ranikot shale varies from $0.23 \mathrm{mg}$ $\mathrm{HC} / \mathrm{g}$ rock to $90.79 \mathrm{mg} \mathrm{HC} / \mathrm{g}$ rock, indicating poor to very good hydrocarbon generation potential. In the present investigation, Van Krevelen diagrams were used to deduce the Type of kerogen in shales (Van Krevelen, 1993). Types III-IV (Figures 4-5) kerogens were identified in the Ranikot shales. Type IV kerogen is inert and Type III kerogen can generate the gas. Hydrogen Index (HI) of the Ranikot Formation shales are ranging between 24 to $234 \mathrm{mg} \mathrm{HC} / \mathrm{g}$ TOC. The values point out that the Type of organic matter is predominantly III/IV. The average value of the Oxygen Index (OI) of the Ranikot shales is $114 \mathrm{mg} \mathrm{CO} / \mathrm{g}$ TOC suggests that organic matter can generate gas only. The HI and OI values of the Ranikot shales are compared with Peters (1986). HI and OI based on pyrolysis using source rock analysis apparatus do not always precisely indicate the Types of kerogen and types of hydrocarbon that may be produced by the source rocks (Dembicki, 2009; Abbassi et al., 2016). Therefore the Type of kerogen of the Ranikot shale is further integrated with maceral analyses.

The dominant maceral type of Ranikot Formation shale of Ranpethani well $(50 \mathrm{~m})$ is vitrinite (Figure 6). The vitrinite content of this shale is higher than $50 \%$. However, the shale is also characterized by 10\% liptinite (Figure. 6) and 3\% inertinite (Table 1). The maceral analyses of the Ranikot shale in Hashim Kher well $(400 \mathrm{~m})$ indicate that $50 \%$ is vitrinite (Figure. 7). The maceral examination of the shale also shows $20 \%$ liptinite (Figure 7 ). The inertinite of the shale is $4 \%$ (Table 1). More evidence came from maceral data that the Type of kerogen present in shales is Types II-III (mixed kerogen). The mixed kerogen Types (II-III) reflect a mixture of terrestrial and marginal marine organic matter with different capabilities to generate oil and gas (Peters et al., 2005). The expected type of hydrocarbon of the Ranikot shale is inferred from the relative percentage composition of vitrinite, liptinite, and inertinite. The percentage composition of macerals (vitrinite, liptinite, and inertinite) is plotted in a ternary diagram (Tissot \& Welte, 1984; Hakimi \& Ahmed, 2016). The diagram (Figure 8) suggests that the Ranikot shales can be expected to generate gas since the organic matter is dominated by vitrinite. 
Table 1. Showing Rock-Eval pyrolysis parameters, vitrinite reflectance, and methylphenanthrene indices of Ranikot Formation shales.

\begin{tabular}{|c|c|c|c|c|c|c|c|c|c|c|c|}
\hline Well & $\begin{array}{l}\text { Depth } \\
\text { (m) }\end{array}$ & $\begin{array}{l}\text { TOC } \\
\text { (Wt. } \\
\% \text { ) }\end{array}$ & $\begin{array}{l}\mathrm{S}_{1} \\
\mathrm{mg} / \mathrm{g}\end{array}$ & $\begin{array}{l}\mathrm{S}_{2} \\
\mathrm{mg} / \mathrm{g}\end{array}$ & $\begin{array}{l}\mathrm{HI} \\
\mathrm{mg} / \\
\mathrm{g}\end{array}$ & $\begin{array}{l}\text { OI } \\
\mathrm{mg} / \mathrm{g}\end{array}$ & $\begin{array}{l}\text { Tma } \\
\mathrm{x} \\
\left({ }^{\circ} \mathrm{C}\right)\end{array}$ & $\begin{array}{l}\text { VR } \\
(\%)\end{array}$ & $\begin{array}{l}\mathrm{GP} \\
\left(\mathrm{S}_{1}+\mathrm{S}_{2}\right) \\
\mathrm{mg} / \mathrm{g}\end{array}$ & $\begin{array}{l}\text { MP-1 } \\
\& \\
\text { MP-2 }\end{array}$ & $\begin{array}{l}\text { Inerti } \\
\text { nite } \\
(\%)\end{array}$ \\
\hline \multirow[t]{9}{*}{ Ranpethani } & 50 & 12.64 & 1 & 14.16 & 112 & 74 & 407 & 0.35 & 15.16 & $\begin{array}{l}0.34 \\
0.44\end{array}$ & 3 \\
\hline & 60 & 2.83 & 0.07 & 2.06 & 73 & 141 & 435 & & 2.13 & & \\
\hline & 110 & 1.42 & 0.02 & 0.33 & 23 & 196 & 430 & & 0.35 & & \\
\hline & 120 & 1.5 & 0.02 & 0.35 & 23 & 165 & 435 & & 0.37 & & \\
\hline & 140 & 1.2 & 0.02 & 0.41 & 34 & 150 & 436 & & 0.43 & & \\
\hline & 150 & 0.65 & 0.02 & 0.21 & 32 & 268 & 431 & & 0.23 & & \\
\hline & 170 & 0.9 & 0.04 & 0.32 & 36 & 240 & 429 & & 0.36 & & \\
\hline & 180 & 0.93 & 0.04 & 0.36 & 39 & 243 & 439 & & 0.4 & & \\
\hline & 250 & 1.91 & 0.11 & 0.94 & 49 & 134 & 422 & & 1.05 & & \\
\hline \multirow[t]{9}{*}{ Hashim Kher } & 400 & 37.62 & 2.82 & 87.97 & 234 & 115 & 414 & 0.54 & 90.79 & & 4 \\
\hline & 410 & 2.68 & & & & & & & & & \\
\hline & 420 & 3.48 & 0.00 & 1.67 & 59 & 62 & 431 & & 1.67 & & \\
\hline & 430 & 1.04 & 0.00 & 1.52 & 57 & 66 & 432 & & 1.52 & & \\
\hline & 490 & 1.58 & 0.03 & 6.97 & 200 & 69 & 434 & & 7 & & \\
\hline & 500 & 3.38 & 0.00 & 3.42 & 101 & 46 & 434 & & 3.42 & & \\
\hline & 510 & 4.17 & 0.00 & 4.67 & 112 & 41 & 434 & & 4.67 & & \\
\hline & 530 & 2.63 & 0.00 & 2.93 & 111 & 56 & 423 & & 2.93 & & \\
\hline & 570 & 1.35 & 0.00 & 0.55 & 41 & 101 & 433 & & 0.55 & & \\
\hline \multirow[t]{3}{*}{ Sono Deep } & 480 & 2.87 & 0.10 & 3.45 & 120 & 57 & 425 & & 3.55 & & \\
\hline & 510 & 5.96 & 0.16 & 11.5 & 193 & 36 & 420 & & 11.66 & & \\
\hline & 530 & 6.75 & 0.26 & 15.1 & 200 & 31 & 418 & & 15.36 & & \\
\hline
\end{tabular}

TOC: total organic carbon; $\mathrm{T}_{\max }$ : maximum temperature; $\mathrm{S}_{1}$ : free hydrocarbons; $\mathrm{S}_{2}$ : remainig potential; HI: hydrogen index; OI: oxygen index; VR: vitrinite reflectance (Ro); MP-1 \& MP-2: methylphenanthrene indices; (GP): generation potential.

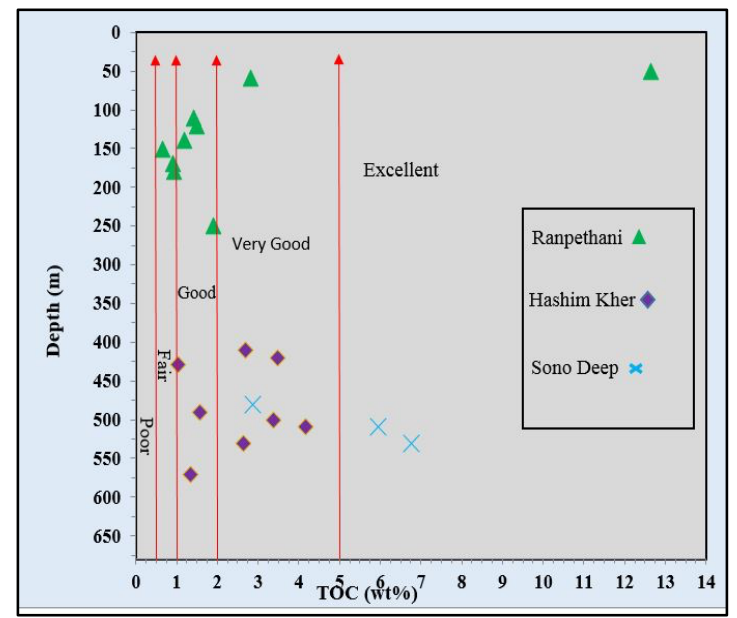

Fig. 3. Showing cross-relation between TOC and depth of the Ranikot shales (diagram boundaries are after Tissot and Welte, 1984; Peters and Cassa, 1994). 


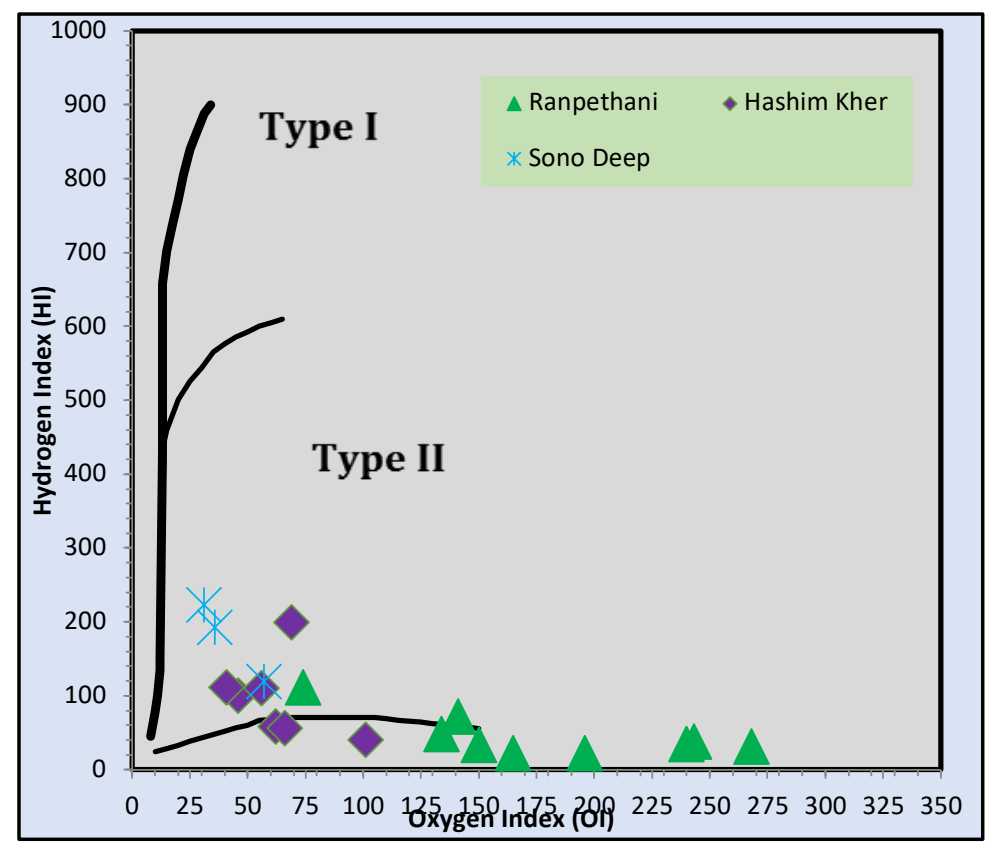

Fig. 4. Showing cross plot relation between HI and OI of the Ranikot shales (diagram boundaries are after Tissot and Welte, 1984; Peters and Cassa, 1994).

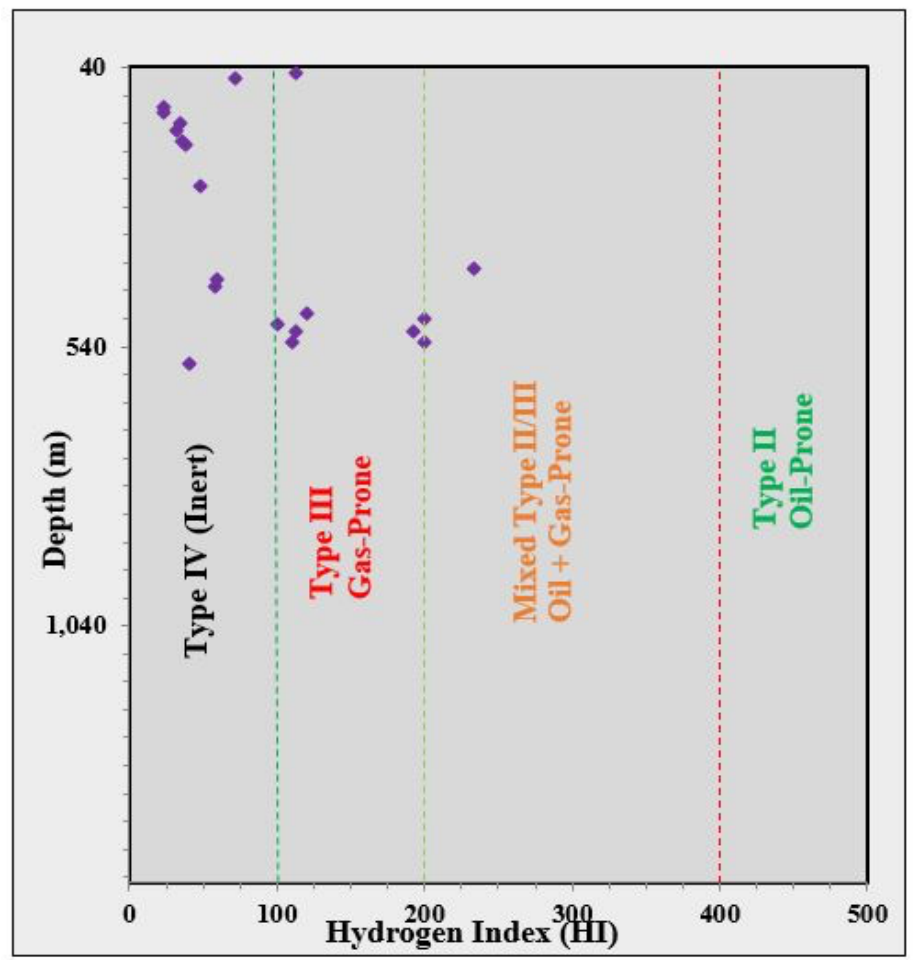

Fig. 5. Showing cross plot relation between $\mathrm{HI}$ and depth of the Ranikot shales (diagram boundaries are after Tissot and Welte, 1984; Peters and Cassa, 1994). 


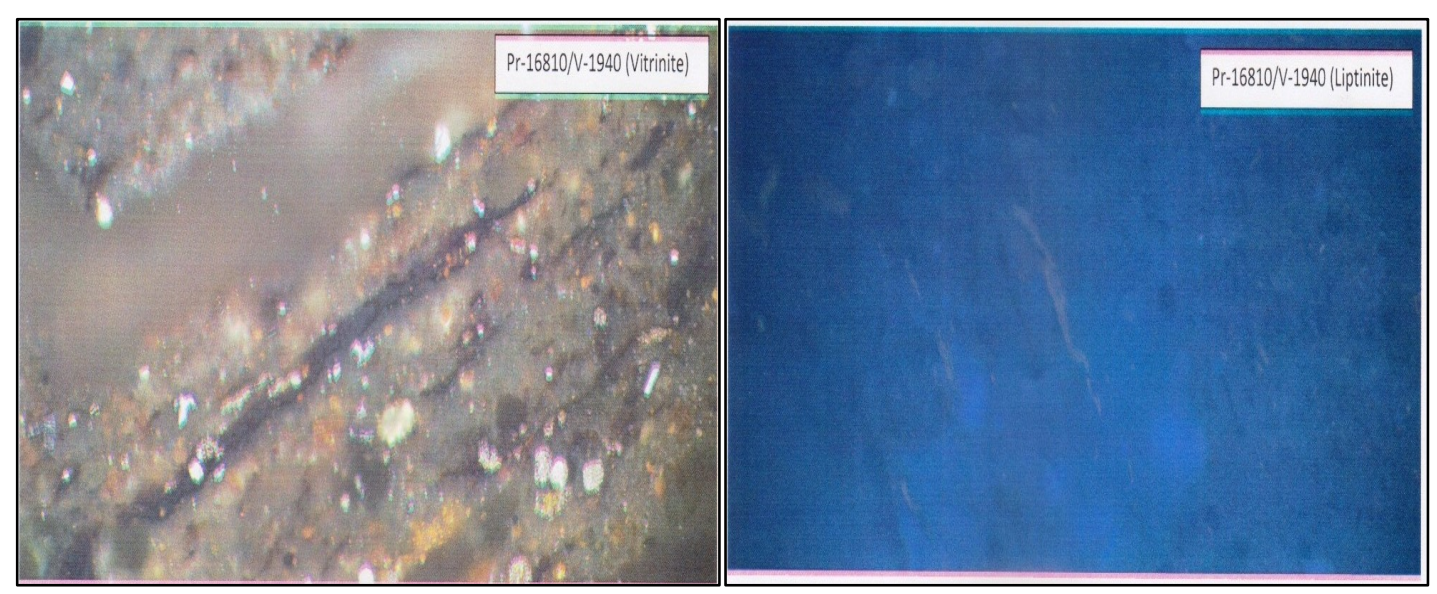

Fig. 6. Photomicrographs (Pr-16810/V-1940) of Ranikot shales in Ranpethani well-showing vitrinite and liptinite.

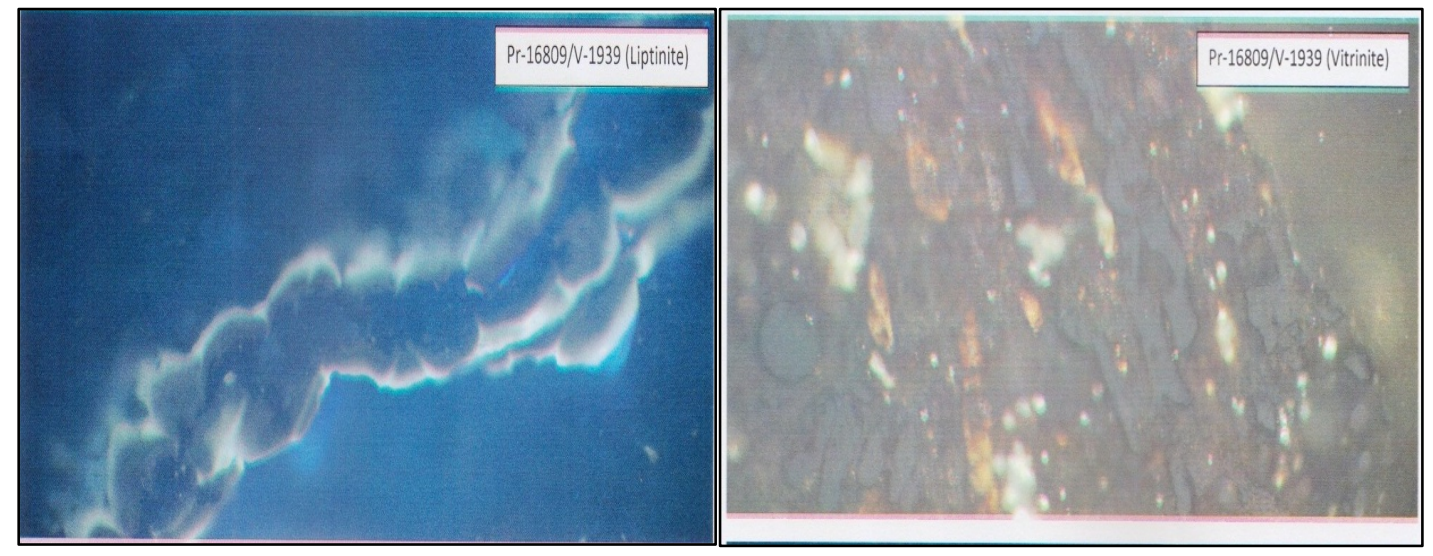

Fig. 7. Photomicrographs (Pr-16809/V-1939) of Ranikot shales in Hashim Kher well-showing vitrinite and liptinite.

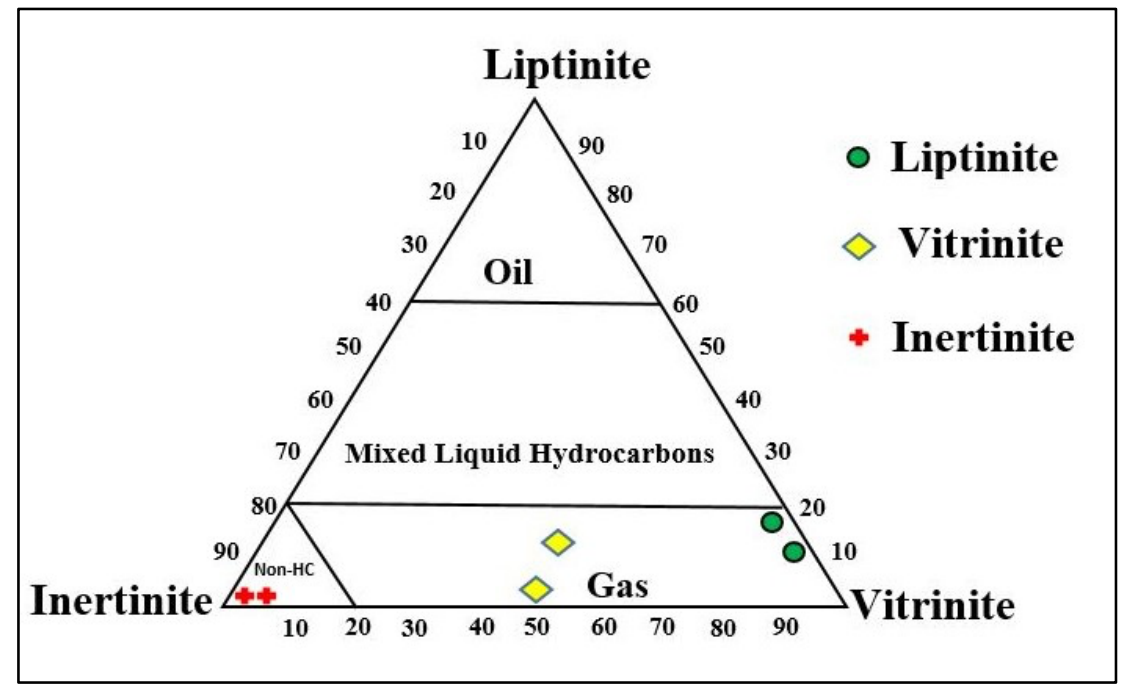

Fig. 8. Ternary diagram of the maceral composition, showing expected hydrocarbon phase of the Ranikot Formation shales (after Tissot and Welte, 1984). 


\subsection{Thermal Maturity}

Vitrinite reflectance (Ro) values for oil window ranges from 0.6 to $1.3 \%$ Ro and values higher than $2.0 \%$ Ro show dry gas generation phase (Tissot \& Welte, 1984; Teichmüller et al., 1998; Killops and Killops, 2005). Vitrinite reflectance values of the Ranikot Formation vary from 0.35 to 0.54 $\%$ Ro (Table 1) and indicate that shales are immature for the generation of hydrocarbons. The Ranikot Formation has pyrolysis $\mathrm{T}_{\max }$ values in the range of 407 to $439^{\circ} \mathrm{C}$ (Table 1) signifying predominantly that shales are immature for the generation of hydrocarbon. $\mathrm{T}_{\max }$ values of the Ranikot Formation shales are correlated with Peters \& Cassa (1994) and Bacon et al. (2000). $T_{\max }$ data of Ranikot Formation are plotted versus depth (Figure. 9), indicating that shales are immature for the generation of hydrocarbons. The thermal maturity of organic matter in Ranikot shale is also expressed by methylphenanthrene indices (MP-1 and MP-2). The ratios of alkyl Phenanthrene are significant parameters to evaluate the maturity of organic matter in the source rocks (Radke et al., 1985; Radke, 1988). As reported by Radke (1988), the comparative abundances of the alkyl homologs of phenanthrene were applied to calculate the vitrinite reflectance (Ro \%). The values such as $0.5 \%, 0.65-1.35 \%$, and $1.35-2.0 \%$ are used for immature, oil windows, and higher maturity respectively (Radke and Welte, 1983; Boreham et al., 1988). The MP-1 and MP-2 values of the Ranikot Formation range from 0.34 to $0.44 \%$ (Table 1: Figure 10), showing shales are thermally immature for the generation of hydrocarbons.

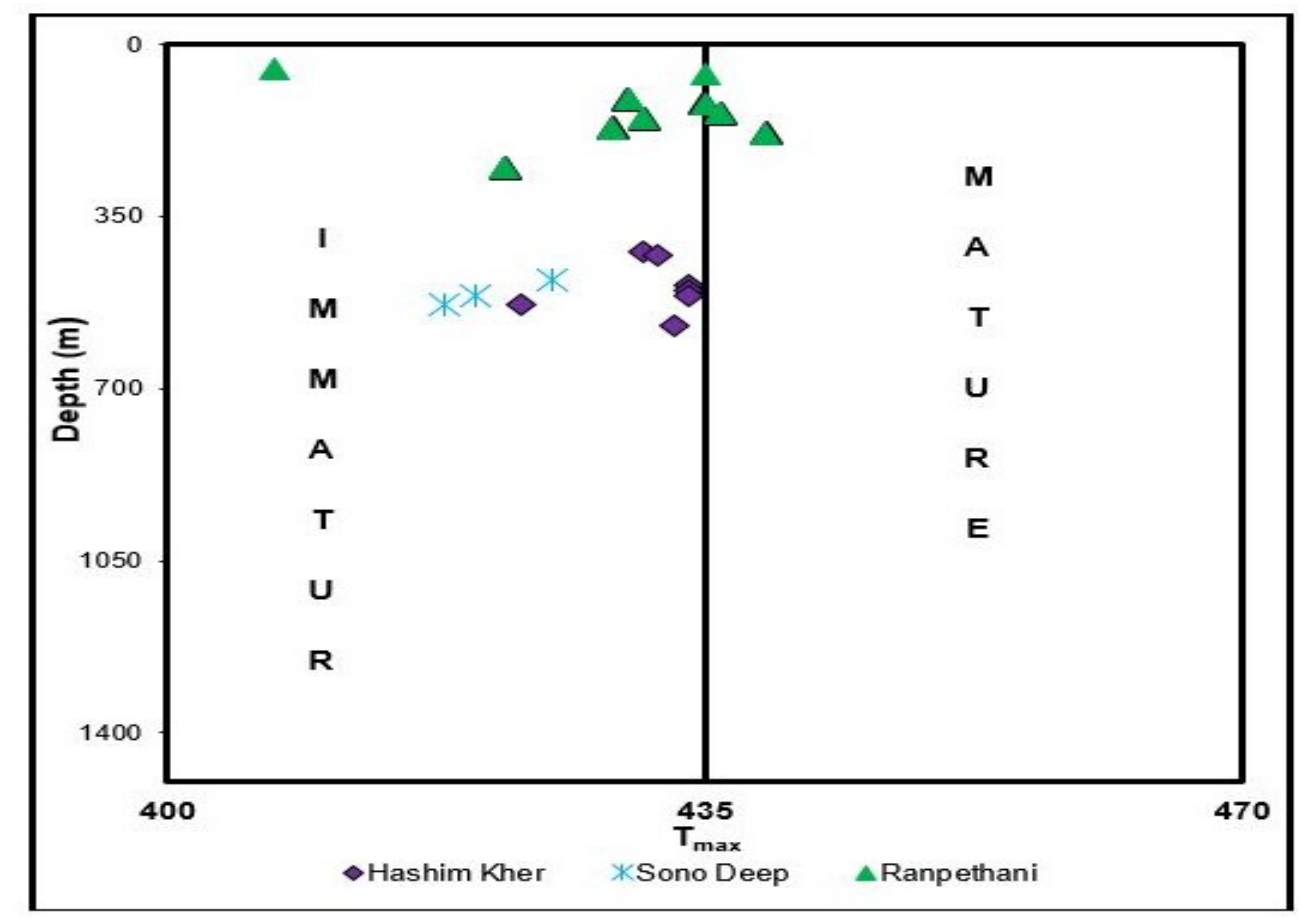

Fig. 9. A plot of Tmax versus depth for Ranikot shales (diagram boundaries are after Tissot and Welte, 1984; Peters and Cassa, 1994). 


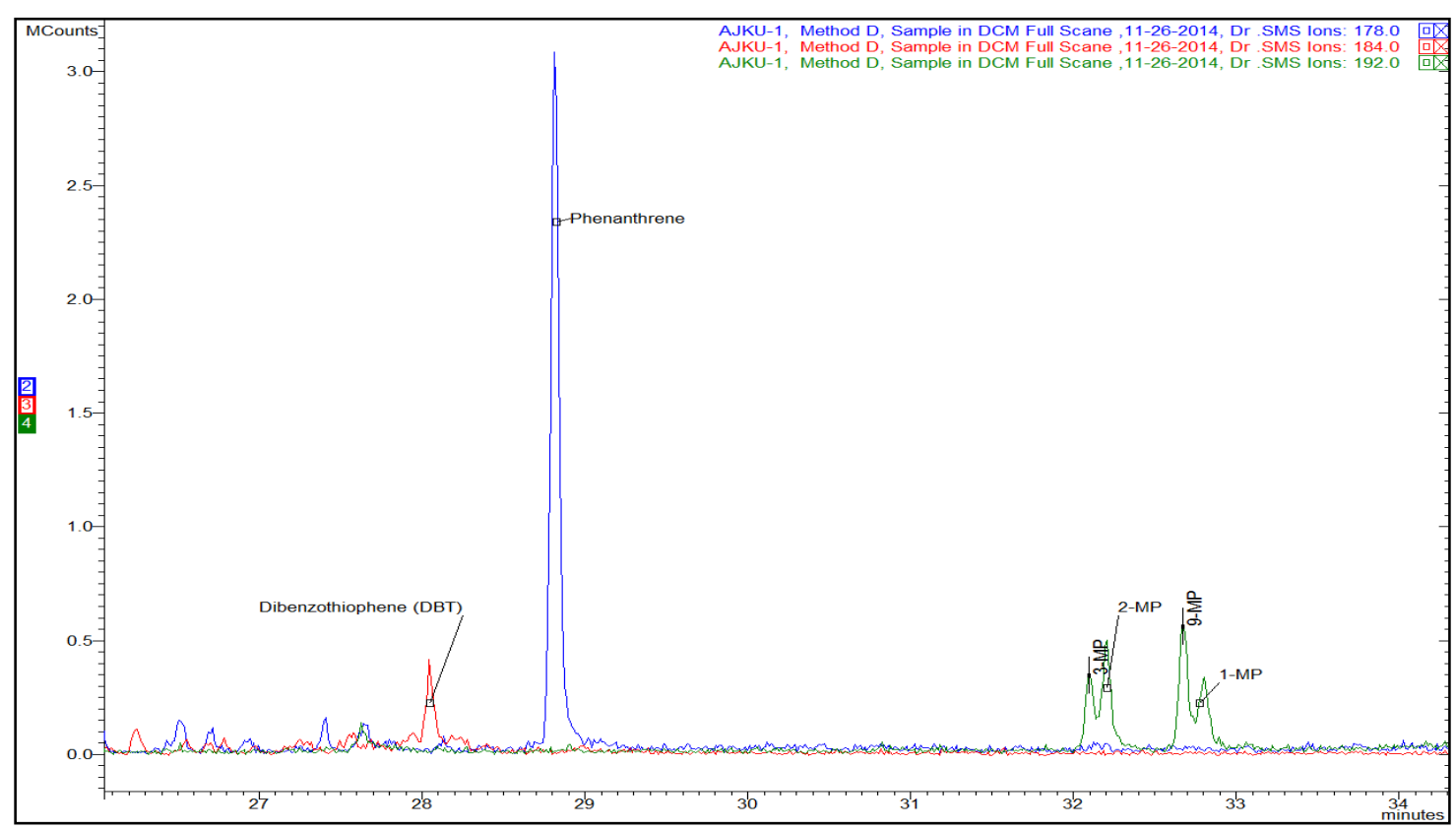

Fig. 10. Fragmentogram (m/z 178, 184, 192) of the Ranikot shale extracts showing the distribution of phenanthrene, methylphenanthrene (MP), and dibenzothiophene (DBT).

\subsection{Source of organic matter and depositional environment}

Normal alkanes of low molecular weight $\left(<\mathrm{C}_{20}\right)$ are principally originated from algae and microorganisms (Cranwell, 1977). The intermediate molecular weight (n- $\left.\mathrm{C}_{21}-\mathrm{C}_{25}\right)$ normal alkanes are derived from aquatic macrophytes (Ficken et al., 2000). Eglinton \& Hamilton (1967) suggested that long straight-chain alkanes $\left(>n-C_{27}\right)$ are the diagnostic of higher land plants. The normal alkanes of the Ranikot shale in the Ranpethani well are dominated by $n-\mathrm{C}_{25}$ (Figure. 11). The n$\mathrm{C}_{25}$ in the Ranikot Formation shows marine macrophytes were contributed to shales. The $n-\mathrm{C}_{25}$ in Ranikot Formation is followed by $\mathrm{n}-\mathrm{C}_{19}$ and $\mathrm{n}-\mathrm{C}_{18}$, suggesting algae and microorganism input in shales. The lesser relative abundance of the normal-alkanes lie in the typical range of $n-\mathrm{C}_{20}$ to $\mathrm{n}$ $\mathrm{C}_{32}$ were also recorded in the shale (Figure 11). These normal alkanes suggest the influx of terrigenous plants in the Ranikot shale. The mixed origin (Types II/III) of the organic matter of the Ranikot shale is consistent with maceral data.

The depositional setting of the Ranikot Formation shales in the Ranpethani well is deduced from geochemical and geological data. The dibenzothiophene/phenanthrene (DBT/P) ratio can be used to infer the source rock depositional setting and lithologies. Marine shales have a DBT/P ratio less than 1 and carbonates have higher than 1 (Hughes et al., 1995). The DBT/P ratio for the Ranikot shale is 0.11 , which indicates that the rock unit is marine shale. The phytane $/ \mathrm{n}-\mathrm{C}_{18}$ value for marine shale is greater than 0.3 (Peter \& Moldowan, 1993; Palacas, 1984; Connan et al., 1986). The phytane $/ \mathrm{n}-\mathrm{C}_{18}$ value of the Ranikot shale is 0.53 . The value is the indicative of marine environment. The marine anoxic condition is further supported by pyrite and glauconite (Figure 12). 


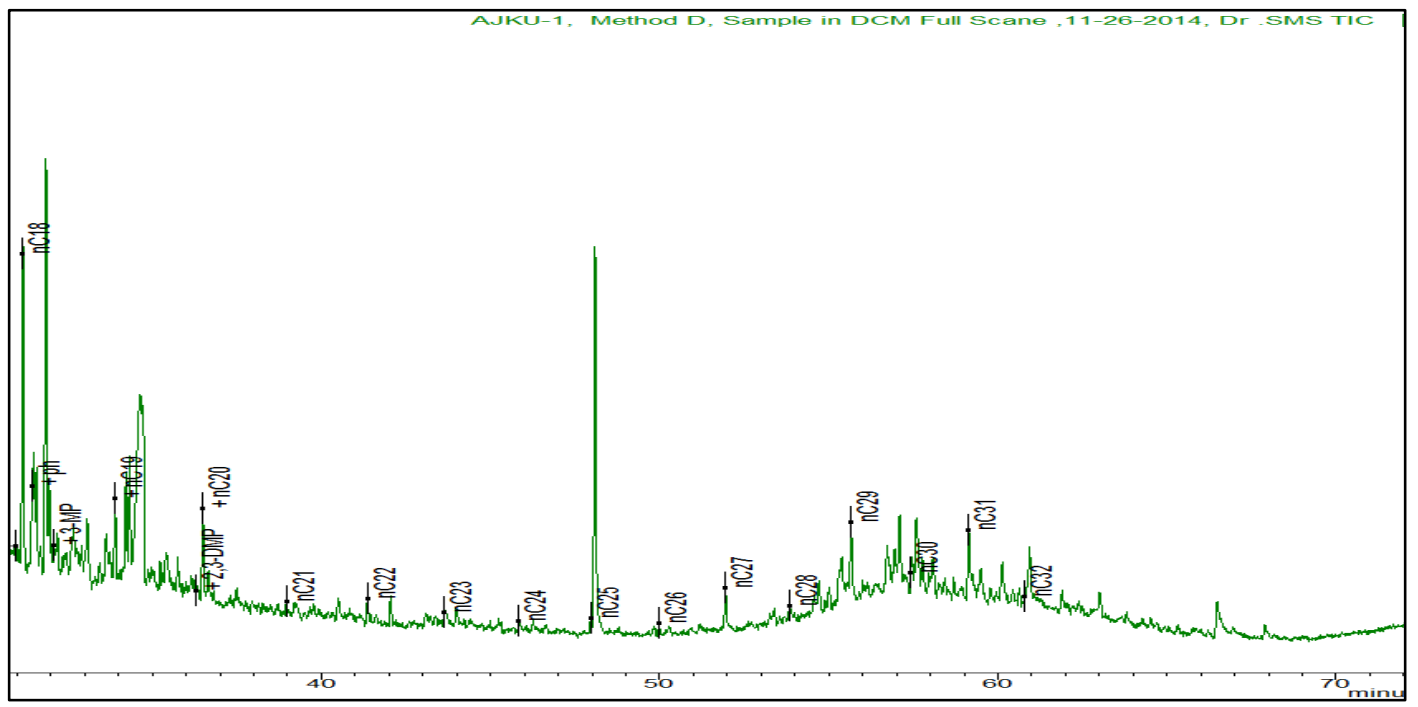

Fig. 11. Whole Rock Extract chromatogram of the Ranikot shale in Ranpethani well-showing distribution of saturates and aromatics hydrocarbons.
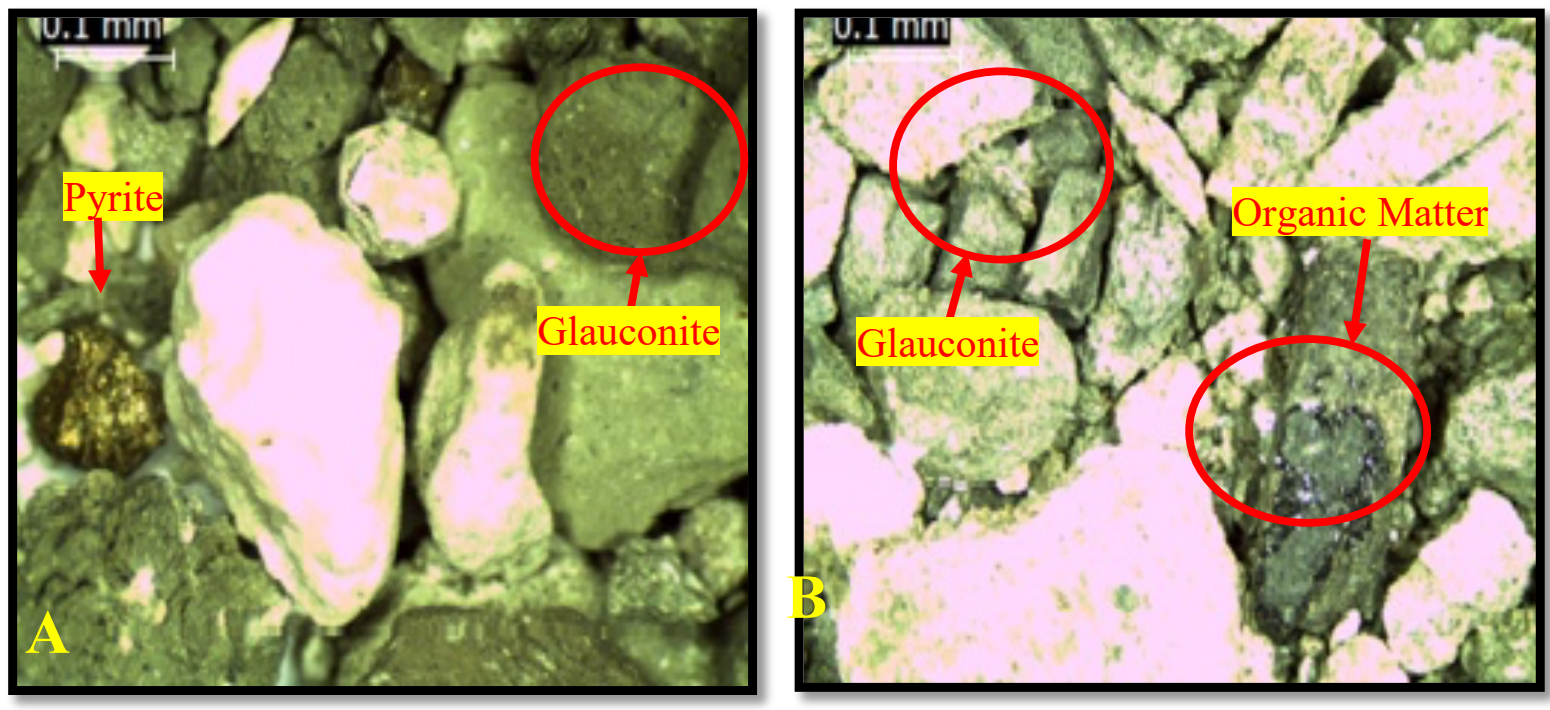

Fig. 12. Photomicrographs (A\& B) of the Ranikot Formation shales showing pyrite, glauconite, and organic matter.

\subsection{Mineralogical characterization of Ranikot shales}

The XRD analysis of the shales of the Ranikot Formation is carried out (Hashim Kher \& Ranpethani wells) to understand their mineralogy. The mineralogical composition of Ranikot shales is recognized by correlating the latticed-spacing values with the International Centre for 
Diffraction Data (ICDD, 2001). The XRD results of the Ranikot Formation shales are demonstrated in Table 2: Figure 13. The quartz content of the Ranikot shales is ranging from 39.5 to 50.9 wt. \%, with an average value of $22.6 \mathrm{wt}$. \%. The clay content of the Ranikot shale varies from 18.2 to 36.9 wt. \%. The average value of the clay is $11.02 \mathrm{wt}$. \%. XRD of the Ranikot shales indicate the dominant clays are kaolinite and gibbsite. The total carbonate (calcite $\&$ dolomite) content value of the shale is 23.78 wt. \%. According to Bowker (2002), the high gas production of the Barnett shale is due to its brittleness and response to stimulation. The Barnett shale is brittle because of the high percentages of quartz and carbonate contents (Gas Research Institute, 1991; Martineau, 2001). Martineau (2001) suggested that without these mineralogical characteristics Barnett shale gas would not be a successful play. In the light of Barnett shale gas, the Ranikot shales are mineralogically characterized by quartz, clay, and carbonate contents. Total quartz, clays, and carbonates (Table 2) contents of the Ranikot shales are plotted in the ternary diagram (Figure. 14). The diagram suggested that Ranikot shales are brittle as dominated by high quartz (39.5 to 50.9 wt. $\%)$ content.

Table 2. Showing XRD data of the Ranikot Formation shales.

\begin{tabular}{|c|c|c|c|c|c|c|c|}
\hline Well & $\begin{array}{l}\text { Standard } \\
\text { d-spacing } \\
\mathrm{A}^{0}\end{array}$ & $\begin{array}{l}\text { Observed } \\
\text { d-spacing } \\
\mathrm{A}^{0}\end{array}$ & Mineral & $\begin{array}{l}\text { Wt. } \\
(\%)\end{array}$ & $\begin{array}{l}\text { Total } \\
\text { Quartz } \\
\text { Wt. (\%) }\end{array}$ & $\begin{array}{l}\text { Total } \\
\text { Carbonates } \\
\text { Wt. (\%) }\end{array}$ & $\begin{array}{l}\text { Total } \\
\text { clays } \\
\text { Wt. }(\%)\end{array}$ \\
\hline \multirow{8}{*}{$\begin{array}{l}\text { Hashim } \\
\text { Kher }\end{array}$} & 7.17 & 7.13 & Kaolinite & 10.80 & \multirow[t]{8}{*}{50.9} & \multirow[t]{8}{*}{23.78} & \multirow[t]{8}{*}{18.2} \\
\hline & 4.26 & 4.26 & Quartz & 9.4 & & & \\
\hline & 3.568 & 3.56 & Kaolinite & 7.4 & & & \\
\hline & 3.344 & 3.34 & Quartz & 34.6 & & & \\
\hline & 3.036 & 3.03 & Calcite & 11.89 & & & \\
\hline & 2.807 & 2.80 & Dolomite & 11.89 & & & \\
\hline & 2.709 & 2.70 & Pyrite & 6.9 & & & \\
\hline & 1.818 & 1.81 & Quartz & 6.9 & & & \\
\hline \multirow[t]{7}{*}{ Ranpethani } & 7.17 & 7.1 & kaolinite & 18.5 & \multirow[t]{7}{*}{39.5} & \multirow[t]{7}{*}{-} & \multirow[t]{7}{*}{36.9} \\
\hline & 4.361 & 4.35 & Gibbsite & 6.4 & & & \\
\hline & 3.514 & 3.56 & kaolinite & 12 & & & \\
\hline & 3.344 & 3.344 & Quartz & 39.5 & & & \\
\hline & 3.059 & 3.058 & Gypsum & 5.3 & & & \\
\hline & 2.71 & 2.71 & Hematite & 12.6 & & & \\
\hline & 1.633 & 1.633 & Pyrite & 5.3 & & & \\
\hline
\end{tabular}



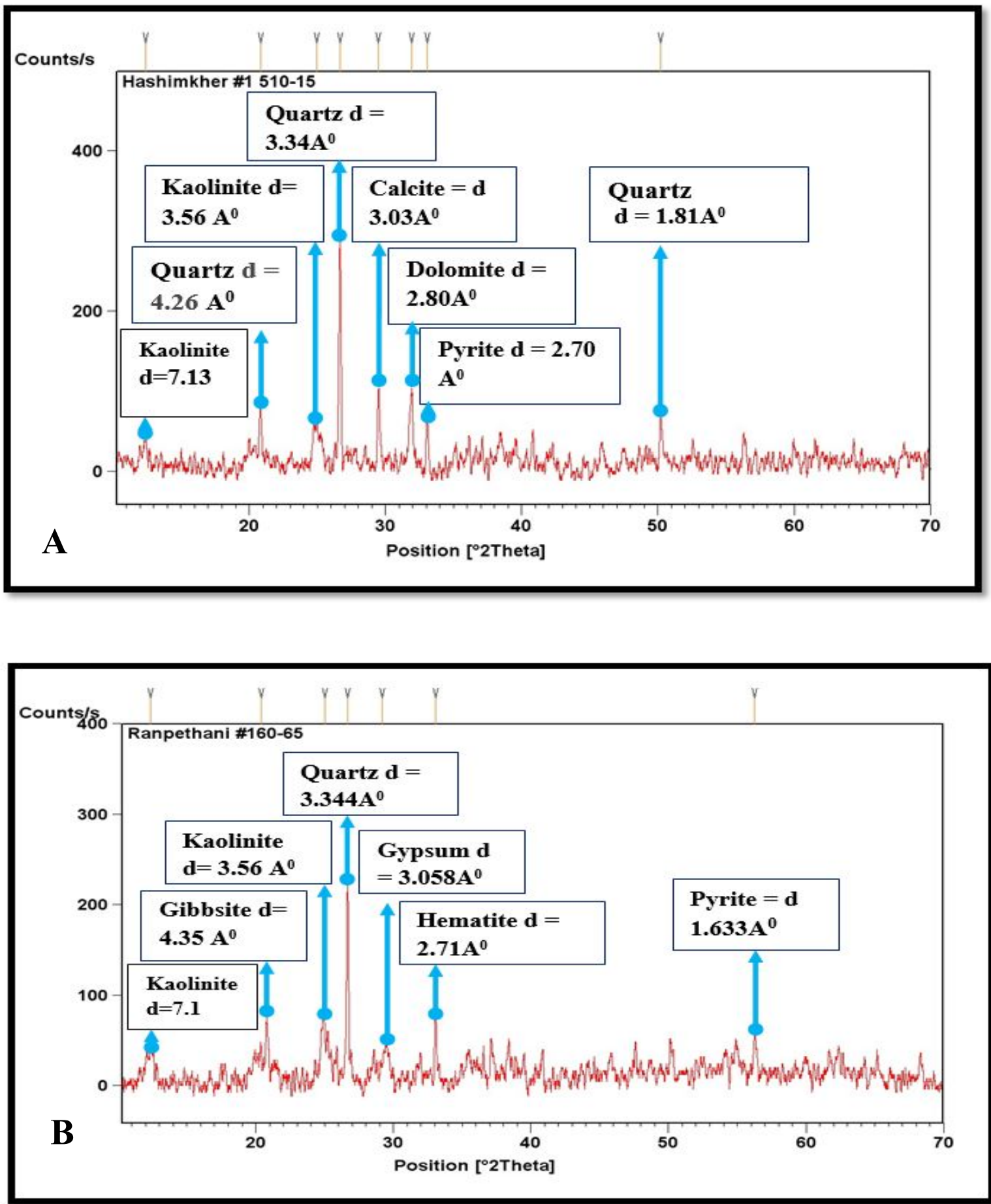

Fig. 13. Powder $x$-ray diffraction pattern of the Ranikot shales in Ranpethani (A) and Hashim Kher (B) wells. 


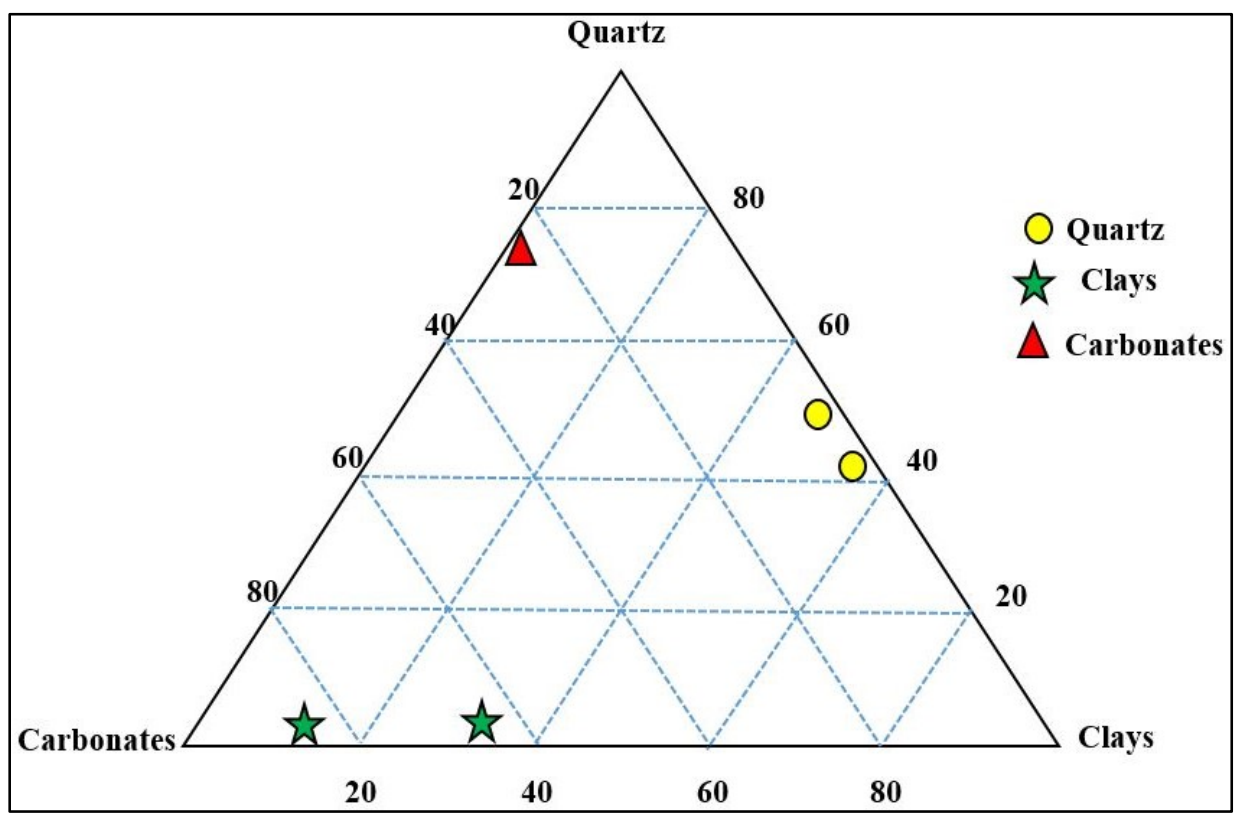

Fig. 14. Ternary diagram showing the mineralogical distribution of quartz, carbonates, and clays of Ranikot Formation shales.

\subsection{Ranikot Formation as a shale gas plays}

The prerequisites for a shale can become an unconventional shale gas resource are enough organic matter, maturity, porosity, permeability, pore anatomy, and the brittleness (Josh et al., 2012). Slatt and Rodriguez (2012) suggested that productive shale gas has typically thickness greater than $200 \mathrm{ft}$ $(65 \mathrm{~m})$, with a TOC value higher than $3 \mathrm{wt}$. \%. In the current research three aspects are studied for Ranikot shale to act as a shale gas resource. Based on high TOC content ( 0.65 to $37.62 \mathrm{wt}$. \%) and GP (0.23 mg HC/g rock to $90.79 \mathrm{mg} \mathrm{HC} / \mathrm{g}$ rock), the Ranikot Formation shales in Southern Indus Basin are expected to act as shale gas plays. In terms of brittleness, the Ranikot Formation shale is dominated by $50.9 \mathrm{wt}$ \% quartz. This high quartz content marks the Ranikot shale brittle. Although geochemical parameters ( $\mathrm{T}_{\max }$, vitrinite reflectance, methylphenanthrene indices) reflect that Ranikot shales are immature for the generation of hydrocarbon, moreover Antrim shale of USA is the most productive biogenic gas plays in the Michigan Basin although their organic matter is thermally immature (Shurr and Ridgley, 2002). In the present research, the Ranikot Formation shale is studied at very shallow depths (Table 1), consequently, no considerable thickness and maturity of the shales are documented. US EIA (2015) has been studied (well: Sann \# 1) the Ranikot Formation shale in the Southern Indus Basin at a depth of 880 meters. US EIA (2015) reported net thickness of the Ranikot Formation shale is $200 \mathrm{ft}$ with vitrinite reflectance $0.7 \%$ to $1.0 \%$, Ro. The present and US (EIA, 2015) investigations of the Ranikot Formation marked the shale a more attractive target for shale gas resources. However, a more comprehensive study of porosity, permeability, gas in place estimates, and type of shale gas system of the Ranikot Formation shale needs to be carried out . 


\section{Conclusion}

Organic geochemical and mineralogical analyses were carried out in this research to evaluate the hydrocarbon source potential and bulk mineralogy of the Ranikot Formation shales from the selected areas of Southern Indus Basin Pakistan. The organic geochemical and mineralogical results of the Ranikot shales are summarized as follows:

1. The average TOC contents of the Ranikot shales indicate very good hydrocarbon source rock potential.

2. Rock-Eval pyrolysis data reflect that Ranikot shale is characterized by Types III/IV kerogen. Moreover, maceral data show Types II-III kerogen, and only 3-4\% inertinite is recorded in Ranikot shales.

3. Maturity parameters indicate that the Ranikot shales are immature for hydrocarbon generation.

4. Marine macrophytes, algae, and land plant inputs in the organic matter of the Ranikot shales are evident from normal alkane data.

5. Dibenzothiophene/phenanthrene ratio, phytane $/ \mathrm{n}-\mathrm{C}_{18}$ ratio, pyrite, and glauconite collectively show that the depositional environment of the Ranikot shale is marine. The XRD analysis of the Ranikot Formation indicates that shale is dominated by quartz.

6. Based on high TOC content, GP, dominant quartz content, and previous US Energy Information Administration investigations, the Ranikot Formation is a reasonable target for shale gas resources.

\section{ACKNOWLEDGMENT}

This research article presents special heartfelt thanks to Oil \& Gas Development Company Limited (OGDCL), Pakistan for providing samples and access to laboratory facilities. The authors are very thankful to anonymous reviewers and editors of the Kuwait Journal of Science for suggesting corrections that have improved the quality of work in this manuscript.

\section{References}

Abbassi, S., Edwards, D.S., George, S.C., Volk, H., Mahlstedt, N., Primio, R., Horsfield, B. (2016). Petroleum potential and kinetic models for hydrocarbon generation from the Upper Cretaceous to Paleogene latrobe Group coals and shales in the Gippsland basin, Australia. Org. Geochem. 91, 54e67.

Ahmad, S., Ahmad, F., AbdUllah., Eisa, M., FarmanUllah., Kaif, K., Khan, S. (2019). Integration of the outcrop and subsurface geochemical data: implications for the hydrocarbons source rock evaluation in the Lower Indus Basin, Pakistan. Journal of Petroleum Exploration and Production Technology, 9:937-951. 
Awan, R.S., Liu, C., Aadil, N., Yasin, Q., Salaam, A., Hussain, A., Yang, S., Jadoon, A.K., Wu, Y., Gul, M.A. (2021). Organic geochemical evaluation of Cretaceous Talhar Shale for shale oil and gas potential from Lower Indus Basin, Pakistan. Journal of Petroleum Science and Engineering, 200, 108404.

Bacon, C.A., Calver, C.R., Boreham, C.J., Leaman, D.E., Morrison, K.C., Revill, A.T., Volkman, J.K. (2000). The petroleum potential of onshore Tasmania-a review. Geological Survey Bulletin 71-93.

Bahman, F.K., Abdullah, F.H., Saleh, A., Alimi H. (2022). Organic geochemical and petrological characteristics of the major lower Createous petroleum source rock (Makhul Formation) in Kuwait-Arabian Gulf. Kuwait Journal of Science vol.49, No.(1).

Biswas, S. K. (1982). Rift basins in western margin of India and their hydrocarbon prospects with special reference to Kutch basin. American Association of Petroleum Geologists 66, 1497-1513.

Boreham, C.J., Crick, I.H., Powell. T.G. (1988). Alternative calibration of the methylphenanthrene index against vitrinite reflectance: application to maturity measurements on oils and sediments. Organic Geochemistry 12, 289-294.

Bowker, K. A. (2002). Recent development of the Barnett Shale play, Fort Worth Basin (extended abs.): Innovative gas exploration concepts, October 1, 2002, Denver, Colorado, 16 p.

Cheema, M. R., Raza, S. M., Ahmed, H., Shah, S. M. (1977). Cenozoic, Stratigraphy of Pakistan.

Connan, J., Bouroullec, J., Dessort, D., Albrecht, P. (1986). The microbial input in carbonateanhydrite facies of a sabkha paleoenvironment from Gutemala: a molecular approach. Organic Geochemistry 10, 29-50.

Cranwell, P. A. (1977). Organic geochemistry of Cam Loch (Sutherland) sediments. Chemical Geology 20, 205-221.

Dembicki, H. (2009). Three common source rock evaluation errors made by geologists during prospect or play appraisals. AAPG (Am. Assoc. Pet. Geol.) Bull. 93, 341-356.

Eglinton, G., Hamilton, R. J. (1967). Leaf epicuticular waxes. Science 156, 1322-1335.

EIA, U.S. (2015). Technically Recoverable Shale Oil and Shale Gas Resources: an Assessment of 137 Shale Formations in 41 Countries outside the United States. US Energy Information Administration, Washington, DC. 
Ehsan, M., Gu, H., Akhtar, M.H., Abbasi, S.S., Ehsan, U. (2018). A geological study of reservoir formations and exploratory well depths statistical analysis in Sindh Province, Southern Lower Indus Basin, Pakistan. Kuwait J. Sci. 45 (2) pp 84-93.

Farah, A., Lawrence, D., DeJong, K. A. (1984). An overview of the Tectonics of Pakistan, in Haq, B.U., and Milliman, J.D., Marine Geology and Oceanography of Arabian Sea and Coastal Pakistan. Van Nostrand Reinhold Company 161-176.

Ficken, K.J., Li, B., Swain, D.L., Eglinton, G. (2000). An n-alkane proxy for the sedimentary input of submerged/floating freshwater aquatic macrophytes. Organic Geochemistry 31, 745-749.

Gas Research Institute (1991). Formation evaluation technology for production enhancement: Log, core, and geochemical analyses in Barnett Shale, Mitchell Energy Corp., Thomas P. SimsNo.2, Wise County, Texas: Gas Research Institute Report No. 5086213-1390, 125 p.

Ghori, K.A.R., Haines, P.W. (2007). Paleozoic petroleum systems of the canning basin, Western Australia, Search Discov.

Hakimi, M.H., Ahmed, A.F. (2016). Petroleum source rock characterization and hydrocarbon generation modeling of the Cretaceous sediments in the Jiza sub-basin, eastern Yemen. Mar. Pet. Geol. 75, 356-373.

Hughes, W.B., Holba, A.G., Dzou, L.I. P. (1995). The ratios of dibenzothiophene to phenanthrene and pristane to phytane as indicators of depositional environment and lithology of petroleum source rocks. Geochimica et Cosmochimica Acta 59, 3581-3598.

International Centre for Diffraction Data (2001). Powder Diffraction File USA.

Jarvie, D.M. (1991). Total Organic Carbon (TOC) Analysis in Treatise of Petroleum Geology: Handbook of Petroleum Geology: Source and Migration Processes and Evaluation Techniques, Ed. R.K. Merrill. AAPG., 113-118.

Josh, M., Esteban, L., Delle Piane, C., Sarout, J., Dewhurst, N., Clennell, B. (2012). Laboratory characterization of shale properties. J. Pet. Sci. Eng. 88e89, 107e124.

Killops, S.D., Killops, V.J. (2005). Introduction to Organic Geochemistry, second ed. Blackwell Publishing Limited, U.K.

Martineau, D.F. (2001). Newark East, Barnett Shale field, Wise and Denton counties, Texas; Barnett Shale frac-gradient variances (abs.): AAPG Southwest Section Meeting, March 1-4, 2003, Fort Worth, Texas. 
Palaces, J. G., Anders, D. E., King, J. D. (1984). South Florida basin-prime example of carbonate source rocks of petroleum. In: Palaces, J. G. (ed) Petroleum geochemistry and source rock potential of carbonate rocks. American Association of Petroleum Geologists 18, 71-96.

Peters, K.E. (1986). Guidelines for evaluating petroleum source rock using programmed pyrolysis. American Association of Petroleum Geologists Bulletin 70, 93-117.

Peters, K. E., Moldowan, J. M. (1993). The Biomarker Guide: interpreting Molecular Fossils in Petroleum and Ancient Sediments, Prentice-Hall, Englewood Cliffs New Jersey.

Peters, K.E., Cassa, M.R. (1994). Applied source rock Geochemistry the Petroleum System-from Source to Trap. American Association of Petroleum Geologists Memoir 60, 93-117.

Peters, K.E., Walters, C.C., Moldowan, J.M. (2005). Biomarker guide In: Biomarkers and Isotopes in Petroleum Exploration and Earth History, second ed., vol. 2. University Press, Cambridge, pp. $476 \mathrm{e} 971$.

Powell, C.M.C.A., Farah, A., Dejong, K. A. (1979). Speculative tectonic history of Pakistan and surroundings: some constraints from the Indian ocean, Geodynamics of Pakistan. Geological Survey of Pakistan 5-24.

Quadri, Viqar-Un-Nisa, Shuaib, S. (1968). "Hydrocarbon Prospects of Southern Indus Basin, Pakistan." AAPG Bulletin 70, p. 730-747

Radke, M., Welte, D.H. (1983). The methylphenanthrene index (MPI): a maturity parameter based on aromatic hydrocarbons. Advances in Organic Geochemistry 504-512.

Radke, M., Welte, D.H., Willsch, H. (1985). Maturity parameters based on aromatic Hydrocarbons: influence of the organic matter type. Advances in Organic Geochemistry 10, 5163.

Radke, M. (1988). Application of aromatic compounds as maturity indicators in source rocks and crude oils. Mar. Petrol. Geol. 5, 224-236.

Raza, H. A., Ahmed, A., Ali, S.M. (1990). Pakistan offshore, an attractive frontier, Pakistan, Jr. Hydrocarbon, Research 2, 1-42.

Shah, S.M.I. (1977). Stratigraphy of Pakistan, Government of Pakistan Ministry of Petroleum and Natural Resources. Geological Survey of Pakistan memoir 12. 
Shah, S.M.I. (2009). Stratigraphy of Pakistan, Government of Pakistan Ministry of Petroleum and Natural Resources. Geological Survey of Pakistan memoir 22.

Shah, S.B.A., and Ahmed, A. (2018). Hydrocarbon source rock potential of Paleocene and Jurassic deposits in the Panjpir oilfield subsurface, Punjab Platform, Pakistan. Arabian Journal of Geosciences, 11:607.

Sheikh, N., and Giao P.H. (2017). Evalaution of shale gas potential in the Lower Cretaceous Sembar Formation, the Southern Indus Basin, Pakistan. Journal of Natural Gas Science and Engineering, 44, 162-176.

Shurr, G.W., and Ridgley, J.L. (2002). Unconventional shallow biogenic gas systems. Am. Assoc. Pet. Geol. Bull. 86, 1939-1969. doi: 10.1306/61EEDDC8173E-11D7-8645000102C1865D.

Slatt, R.M., Rodriguez, N.D. (2012). Comparative sequence stratigraphy and organic geochemistry of gas shales: commonality or coincidence? J. Nat. Gas Sci. Eng 8, 68e84.

Teichmüller, M., Littke, R., Robert, P. (1998). Coalification and maturation. In: Taylor, G.H., Teichmüller, M., Davis, A., Diessel, C.F., Littke, R., Robert, P. (Eds.), Organic Petrology. Gebrüder Borntraeger, Berlin, pp. 86e174.

Tissot, B.P., Welte, D.H. (1984). Petroleum Formation and Occurrence, 2nd Edition. Berlin: 608 Springer-Verlag.

Van Krevelen, D.W. (1993). Coal: Typology, Physics, Chemistry, Constitution. Elsevier, Amsterdam, pp. 979.

Zaigham, N.A. (1991). Bela ophiolites and associated mineralization in southern part of axial-belt of Pakistan. Ph.D. thesis, University of Karachi pp 370.

Zaigham, N.A., Mallick, A.K. (2000). Prospect of hydrocarbons associated with the fossil rift structures of southern Indus basin, Pakistan. American Association of Petroleum Geologists Bulletin 84, 1833-1848.

Submitted: $\quad 17 / 08 / 2020$

Revised: $\quad 17 / 03 / 2021$

Accepted: $\quad$ 28/07/2021

DOI: $\quad 10.48129 /$ kjs. 10413 